demonstrated in practically every transformed cell. The in vitro transformations confirm the oncogenic potential of the hybrid virus.

The authors wish to express appreciation to Mr. Richard Maloof for excellent technical assistance.

${ }^{1}$ Huebner, R. J., R. M. Chanock, B. Rubin, and M. J. Casey, these Proceedinas, 52, 1333 (1964)

${ }^{2}$ Black, P. H., W. P. Rowe, H. C. Turner, and R. J. Huebner, these Proceedings, 50, 1148 (1963).

${ }^{3}$ Pope, J. H., and W. P. Rowe, J. Exptl. Med., 120, 121 (1964).

4 Rowe, W. P., and S. G. Baum, these Procendings, 52, 1340 (1964).

5 Rapp, F., J. L. Melnick, J. S. Butel, and T. Kitahara, these Proceedings, 52, 1348 (1964).

6 Rowe, W. P., S. G. Baum, W. E. Pugh, and M. D. Hoggan, J. Exptl. Med., in press.

7 Black, P. H., and W. P. Rowe, J. Natl. Cancer Inst., 32, 253 (1963).

${ }^{8}$ Black, P. H., E. M. Crawford, and L. V. Crawford, Virology, 24, 381 (1964).

9 Todaro, G. J., S. R. Wolman, and H. Green, J. Cell. Comp. Physiol., 62, 257 (1963).

${ }^{10}$ Hayflick, L., Exptl. Cell Res., 37, 614 (1965).

11 Jensen, F., H. Koprowski, and J. A. Pontén, these Proceedings, 50, 343 (1963).

12 Wolman, S. R., K. Hirshhorn, and G. J. Todaro, Cytogenetics, 3, 45 (1964).

${ }^{13}$ Black, P. H., and W. P. Rowe, these Proceedings, 50, 606 (1963).

${ }^{14}$ Huebner, R. J., W. P. Rowe, H. C. Turner, and W. T. Lane, these Proceedings, 50, 379 (1963).

${ }^{15}$ Shein, H. M., J. F. Enders, L. Palmer, and E. Grogan, Proc. Soc. Exptl. Biol. Med., 115, 618 (1964).

${ }^{16}$ Girardi, A. J., F. C. Jensen, and H. Koprowski, J. Cell. Comp. Physiol., 65, 69 (1965).

${ }^{17}$ Koprowski, H., J. A. Pontén, F. Jensen, R. G. Ravdin, P. Moorhead, and E. Saksela, J. Cell. Comp. Physiol., 59, 281 (1962).

18 Shein, H. M., and J. F. Enders, these Proceedings, 48, 1164 (1962).

${ }^{19}$ Rapp, F., J. S. Butel, and J. L. Melnick, Proc. Soc. Exptl. Biol. Med., 116, 1131 (1964).

${ }^{20}$ Habel, K., and B. E. Eddy, Proc. Soc. Exptl. Biol. Med., 113, 1 (1963).

${ }^{21}$ Koch, M., and A. B. Sabin, Proc. Soc. Exptl. Biol. Med., 113, 4 (1963).

22 Defendi, V., Proc. Soc. Exptl. Biol. Med., 113, 12 (1963).

${ }^{23}$ Black, P. H., W. P. Rowe, and H. L. Cooper, these Proceedings, 50, 847 (1963).

${ }^{24}$ Jenisen, F. C., A. J. Girardi, R. V. Gilden, and H. Koprowski, these Proceedings, 52, 53 (1964).

TUMORS INDUCED IN HAMSTERS BY A STRAIN OF ADENOVIRUS TYPE 3: SHARING OF TUMOR ANTIGENS AND "NEOANTIGENS" WITH THOSE PRODUCED BY ADENOVIRUS TYPE 7 TUMORS*

By R. J. Huebner, $\uparrow$ M. J. Casey, $\uparrow$ R. M. Chanock, $\nmid$ and K. Schell $\ddagger$

NATIONAL INSTITUTE OF ALLERGY AND INFECTIOUS DISEASES, NATIONAL INSTITUTES OF HEALTH, BETHESDA, MARYLAND

Communicated June 4, 1965

Recently, we observed tumors induced in hamsters by a strain of type 3 adenovirus which had been isolated from a child with acute respiratory illness. The type 3 inoculum designated as strain 15520 had been carried for seven passages in human diploid cells prior to injection of newborn hamsters. ${ }^{1}$ A subcutaneous tumor appeared 275 days later at the site of injection in one of eight hamsters. When the 
TABLE 1

Oncogenicity of Strains of Adenovirus Types 3 and 7

\begin{tabular}{|c|c|c|c|c|c|c|c|c|c|}
\hline \multirow[b]{2}{*}{ Type } & \multirow{2}{*}{ irus } & \multirow{2}{*}{$\begin{array}{l}\text { Tissue } \\
\text { culture } \\
\text { passage } \\
\text { history }\end{array}$} & \multirow{2}{*}{$\begin{array}{l}\text { Virus dose } \\
\text { HEK } \\
\text { TCID }\end{array}$} & \multirow{2}{*}{$\begin{array}{l}\text { Postinoc. } \\
\text { day tumor } \\
\text { first noted }\end{array}$} & \multicolumn{5}{|c|}{ Hamsters with Tumors on Postinoc. } \\
\hline & & & & & 200 & 250 & 300 & 350 & 400 \\
\hline AD-3 & 15520 & $\mathrm{DT}_{7} \dagger$ & $10^{7.7}$ & 258 & $0 / 8 \ddagger$ & $0 / 8$ & $1 / 8$ & $1 / 8$ & $1 / 8$ \\
\hline & "6 & $\mathrm{DT}_{7}$ & $10^{7.7}$ & 151 & $1 / 17^{5}$ & & & & \\
\hline $\mathrm{AD}_{\text {، }}$ & Pinck. & $\begin{array}{l}\mathrm{HEK}_{5} \\
\mathrm{HEK}_{6}\end{array}$ & $\begin{array}{c}\text { NT } \\
10^{7.0}\end{array}$ & $\begin{array}{l}201 \\
183\end{array}$ & $\begin{array}{l}0 / 18 \\
4 / 7\end{array}$ & $\begin{array}{l}5 / 18 \\
5 / 7\end{array}$ & $8 / 18$ & $9 / 18$ & $9 / 18$ \\
\hline “ & “ & $\mathrm{HEK}_{5} \mathrm{~KB}_{2}$ & $10^{9.2}$ & $\begin{array}{l}100 \\
184\end{array}$ & $1 / 11$ & $1 / 11$ & $1 / 11$ & $2 / 11$ & $2 / 11$ \\
\hline AD-7 & C14500 & $\mathrm{HEK}_{4}$ & $10^{7.8}$ & 209 & $0 / 38$ & $7 / 38$ & $10 / 38$ & $16 / 38$ & $17 / 38$ \\
\hline AD -7 & 55142 & $\mathrm{DT}_{7}$ & $10^{6.2}$ & 335 & $0 / 34$ & $0 / 34$ & $0 / 34$ & $1 / 34$ & $1 / 34$ \\
\hline AD-7 & 19690 & $\mathrm{DT}_{4} \mathrm{~KB}_{2}$ & $10^{7.7}$ & 362 & $0 / 14$ & $0 / 14$ & $0 / 14$ & $0 / 14$ & $2 / 14$ \\
\hline AD-7 & Gomen & $\mathrm{HeLa}_{11} \mathrm{~KB}_{2}$ & $10^{8.2}$ & 363 & $0 / 14$ & $0 / 14$ & $0 / 14$ & $0 / 14$ & $1 / 14$ \\
\hline & & $\mathrm{HeLa}_{11} \mathrm{~KB}_{2}$ & $10^{8.7}$ & 314 & $0 / 14$ & $0 / 14$ & $0 / 14$ & $1 / 14$ & $1 / 14$ \\
\hline
\end{tabular}

NT $=$ Not titered.

* Titers obtained in HEK cultures observed for 28 days.

$\dagger$ Human diploid tissue.

$\ddagger$ No. with tumors/no. on test.

same material was subsequently injected both subcutaneously and intraperitoneally, a tumor was observed intraperitoneally after 151 days in one of 17 hamsters. In its long incubation period prior to tumorigenesis, strain 15520 differed considerably from the prototype strains of adenovirus 12 and 18 which readily induce tumors in 1-4 months. ${ }^{2,} 3$ On the other hand, it resembled five strains of adenovirus type 7 which have also required long periods before producing tumors in hamsters ${ }^{4,5}$ (see Table 1). Contrary to previous reports, ${ }^{2,}{ }^{3}$ the prototype (Gomen) strain of adenovirus type 7 also produced tumors. Since in most cases the infectivity titers of the types 3 and 7 inocula equaled or exceeded that of the types 12 and 18 preparations, ${ }^{2-5}$ it appears that the former two serotypes are somewhat less potent producers of hamster tumors than the latter. The identities of the oncogenic 15520 strain of type 3 and of the several oncogenic strains of type 7 were confirmed by neutralization tests using types 3 and 7 prototype rabbit antisera. All strains gave specific reactions with their respective antisera.

The adenovirus types 3 and 7 tumor cells were easily transplanted to the sub-

TABLE 2

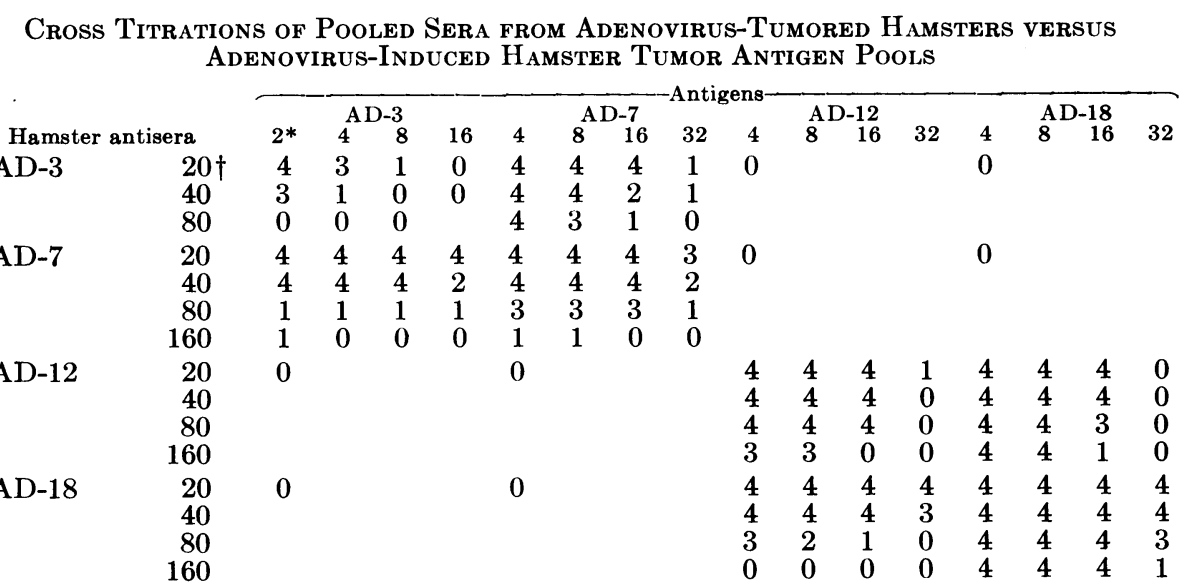

Results are representative of several replicate tests.

* Reciprocal of antigen dilution horizontal column.

$\dagger$ Reciprocal of serum dilution vertical column. 
TABLE 3

Cross Titrations of Pooled Sera from Adenovirus-Tumored Hamsters Versus Tissue Culture-Grown Adenovirus Neohntigens*

\begin{tabular}{|c|c|c|c|c|c|c|c|c|c|c|c|c|c|c|c|c|c|}
\hline \multirow{2}{*}{\multicolumn{2}{|c|}{ Hamster antisera }} & \multicolumn{4}{|c|}{$\mathrm{AD}-3$} & \multicolumn{3}{|c|}{$\mathrm{AD}-7$} & \multicolumn{4}{|c|}{ AD-12 } & \multirow[b]{2}{*}{32} & \multirow[b]{2}{*}{4} & \multicolumn{2}{|c|}{ AD-18 } & \multirow[b]{2}{*}{32} \\
\hline & & $4 \dagger$ & 8 & 16 & 32 & 4 & 8 & 16 & 32 & 4 & & 16 & & & & 16 & \\
\hline AD-3 & $\begin{array}{l}20 \ddagger \\
40 \\
80\end{array}$ & $\begin{array}{l}4 \\
3 \\
2\end{array}$ & $\begin{array}{l}3 \\
1 \\
1\end{array}$ & $\begin{array}{l}2 \\
0 \\
0\end{array}$ & $\begin{array}{l}2 \\
0\end{array}$ & $\begin{array}{l}4 \\
4 \\
3\end{array}$ & $\begin{array}{l}4 \\
4 \\
2\end{array}$ & $\begin{array}{l}3 \\
2 \\
1\end{array}$ & $\begin{array}{l}3 \\
1 \\
0\end{array}$ & 0 & & & & 0 & & & \\
\hline AD-7 & $\begin{array}{r}20 \\
40 \\
80 \\
160\end{array}$ & $\begin{array}{l}\mathbf{4} \\
\mathbf{4} \\
\mathbf{4} \\
\mathbf{4}\end{array}$ & $\begin{array}{l}4 \\
4 \\
4 \\
4\end{array}$ & $\begin{array}{l}4 \\
4 \\
4 \\
4\end{array}$ & $\begin{array}{l}4 \\
4 \\
4 \\
3\end{array}$ & $\begin{array}{l}4 \\
4 \\
4 \\
4\end{array}$ & $\begin{array}{l}4 \\
4 \\
4 \\
4\end{array}$ & $\begin{array}{l}4 \\
4 \\
4 \\
4\end{array}$ & $\begin{array}{l}4 \\
4 \\
4 \\
4\end{array}$ & 0 & & & & 0 & & & \\
\hline AD-12 & $\begin{array}{r}20 \\
40 \\
80 \\
160\end{array}$ & 0 & & & & 0 & & & . & $\begin{array}{l}4 \\
4 \\
4 \\
4\end{array}$ & $\begin{array}{l}4 \\
4 \\
4 \\
3\end{array}$ & $\begin{array}{l}\mathbf{4} \\
\mathbf{4} \\
\mathbf{3} \\
\mathbf{1}\end{array}$ & $\begin{array}{l}4 \\
4 \\
2 \\
0\end{array}$ & $\begin{array}{l}4 \\
4 \\
4 \\
4\end{array}$ & $\begin{array}{l}4 \\
4 \\
4 \\
4\end{array}$ & $\begin{array}{l}4 \\
4 \\
4 \\
3\end{array}$ & $\begin{array}{l}4 \\
4 \\
3 \\
1\end{array}$ \\
\hline AD-18 & $\begin{array}{r}20 \\
40 \\
80 \\
160\end{array}$ & 0 & & & & 0 & & & & $\begin{array}{l}4 \\
4 \\
3 \\
2\end{array}$ & 1 & $\begin{array}{l}1 \\
1 \\
0 \\
0\end{array}$ & $\begin{array}{l}0 \\
0 \\
0 \\
0\end{array}$ & $\begin{array}{l}4 \\
4 \\
4 \\
1\end{array}$ & $\begin{array}{l}4 \\
4 \\
3 \\
1\end{array}$ & $\begin{array}{l}4 \\
4 \\
1 \\
0\end{array}$ & $\begin{array}{l}4 \\
4 \\
1 \\
0\end{array}$ \\
\hline
\end{tabular}

Results are representative of several replicate tests.

$* 20 \times$ concentrated KB cell packs harvested at $72 \mathrm{hr}$.

+ Reciprocal of antigen dilution horizontal column.

$\ddagger$ Reciprocal of serum dilution vertical column.

cutaneous and peritoneal tissues of both newborn and weanling hamsters; and as described previously by Larson et al. ${ }^{6}$ the hamsters carrying primary or transplanted type 7 tumors for several weeks frequently developed complement-fixing (CF) antibodies to antigens present in their homologous tumors. Table 2 shows the homologous and heterologous reactivities of pooled sera from hamsters carrying tumors induced by the various oncogenic adenoviruses. Hamsters carrying type 3 tumors developed CF antibodies less frequently and to lower titers than did those carrying type 7 tumors; however, the reactivity achieved was sufficiently strong to indicate a definite sharing of CF antigens in the tumors induced by types 3 and 7 . There was no crossing with the tumor antigens shared by types 12 and $18,^{7 a}$ or with polyoma, SV40, Schmidt-Ruppin strain Rous sarcoma virus-induced hamster tumor antigens, F. Sa. 3 hamster tumor antigens, ${ }^{7 b, 7 c}$ or with other nonspecific reacting hamster tissue antigens. ${ }^{5}$

As shown in Table 3, nonvirion "neoantigens"7-10a produced in KB tissue cultures early after infection revealed a similar sharing of antigens between types 3 and 7 . The neoantigens produced by several strains each of types 3 and 7 (including the prototypes) were compared by complement fixation tests. All of them gave almost identical reactions with the sera of hamsters carrying types 3 and 7 tumors. Hamsters carrying adenovirus type 7 tumors developed antibodies reactive to the early "cell-pack" antigens (neoantigens) found in tissue cultures infected with certain other adenoviruses. Table 4 shows that a standard pool of sera from hamsters carrying type 7 tumors reacted with neoantigen preparations of types $3,4,11,14$, 16 , and 21, but not with neoantigen preparations of 10 other adenovirus serotypes, SV40, or polyoma, ${ }^{8-10 b}$ whereas the less highly reactive adenovirus type 3 hamster serum reacted only with the types 4 and 16 as well as with the types 3 and 7 neoantigens. There is recent evidence that purified type 21 is tumorigenic to newborn hamsters, but to date types $4,11,14$, and 16 have not been reported to induce tumors in hamsters. ${ }^{4,5}$, 10c As indicated by Pereira et al., ${ }^{11}$ type 31-induced tumors 
TABLE 4

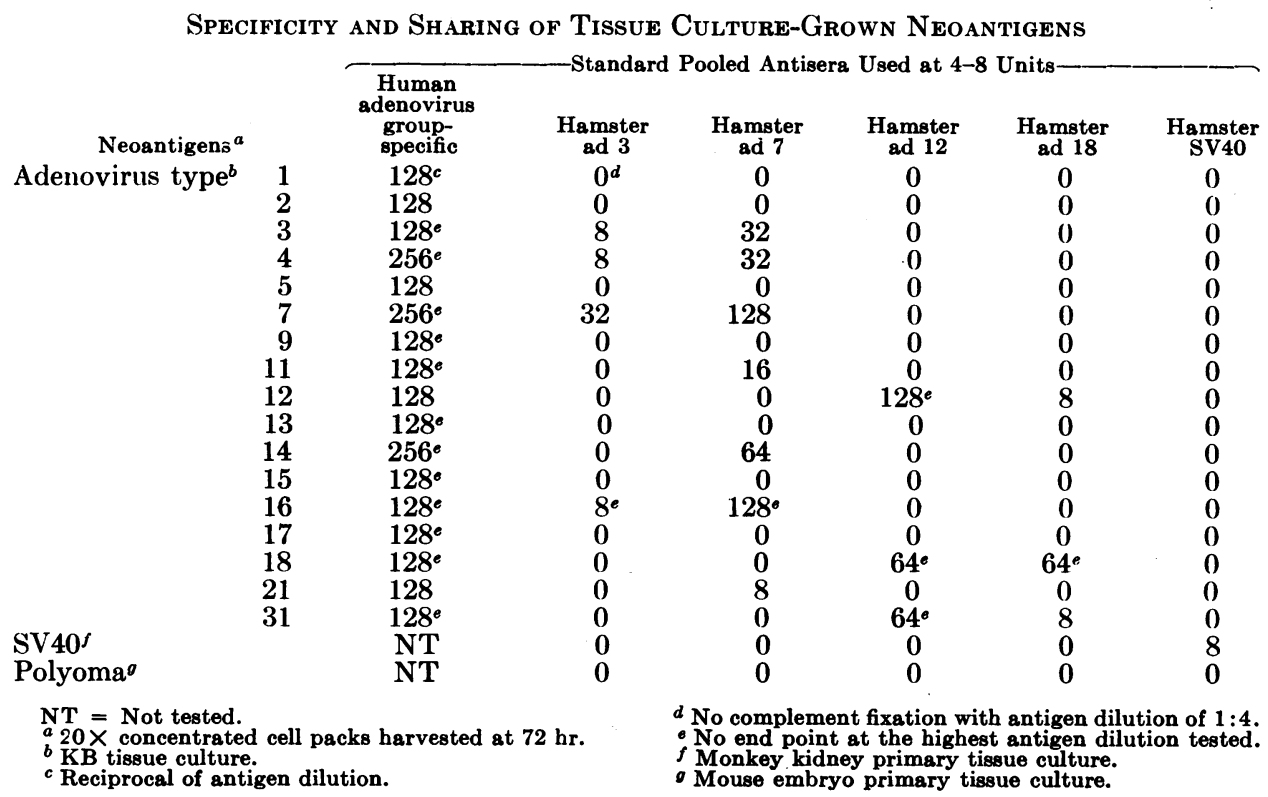

contained antigens shared with those found in types 12 and 18 tumors. Similarly, the type 31 neoantigens crossed with those of types 12 and 18 (Table 4). Thus, insofar as their nonvirion neoantigenic properties are concerned, the tumors induced by adenoviruses 3 and 7 , on the one hand, and by 12,18, and 31, on the other, appear to fall into two distinct categories.

Unlike the hamsters carrying type 12 tumors, ${ }^{7 a}$ none of the hamsters carrying type 3 or type 7 tumors developed virus-neutralizing antibodies at a 1:10 dilution, and CF tests of tumored hamster sera for antibodies to the type-specific " $\mathrm{C}$ " antigen of type 7 were also negative. Only one of 27 hamsters carrying adenovirus type 7 (Pinckney strain)-induced tumors developed CF antibody to the purified virion of adenovirus type 7.

Cells from adenovirus types 3- and 7-induced primary and transplanted hamster tumors were established in tissue culture" following which "packed-cell suspensions"8 from serially passed subcultures were tested for tumor antigens versus their respective positive hamster sera. While tumor antigens were demonstrated in one line of type 3 cells after three tissue culture passages and as early as the primary tissue culture in one line of type 7 cells, several other tissue culture lines derived from types 3 and 7 tumors had little or no complement-fixing antigen when carried as far as the 9 th and 13 th subculture.

Several tumor cell tissue cultures were transplanted to newborn and weanling hamsters. One tissue culture line of type 3 cells having no demonstrable complement-fixing tumor antigen in the 10th subculture was passed four more times and transplanted to newborn hamsters which developed tumors having detectable complement-fixing antigens versus type 7 hamster antisera. When these tumors were transplanted to weanling hamsters, several developed high-titered specific serum antibodies to the tumor and neoantigens of both types 3 and 7 . 
Discussion.-The sharing of neoantigens between adenovirus types $3,4,7,11,14$, 16 , and 21 was not wholly unexpected since serological ${ }^{13-23}$ and other common properties have been described previously for these serotypes. ${ }^{20,} 21,24-29$ Types 12,18 , and 31 , which share neoantigens different from those of the former group, also have other properties in common; most notably, they show crossing in neutralization tests and produce little or no hemagglutinin. ${ }^{11}, 22,23,30$ The neoantigens are cellular products apparently not incorporated in the virion particle. Appearing in the nuclei of cells early after infection before virion antigens are produced, ${ }^{31,32}$ they very likely have a function in the genesis of virus. It is not wholly clear whether or not they are coded for by newly expressed cell genes, or by viral genes. However, the distribution of neoantigen content according to other properties which are clearly expressions of the viral genome tends to support the latter as the determining factor in the production of neoantigens. ${ }^{10 a}$

The oncogenic properties of types 3 and 7 may prove to be particularly important in their possible relationship to human cancer because, unlike types 12 and 18, these two serotypes are known to cause numerous febrile respiratory illnesses in children and in military recruits.

Infections and illnesses due to type 3 have been found wherever studies have been made. Surveys for serum antibodies to type 3 carried out in various parts of the United States, Western Europe, Russia, Japan, Australia, and Formosa indicated that 40-50 per cent of children and 50-70 per cent or more of adults had neutralizing antibodies to type $3 .^{33-44}$

In the Washington, D. C., area where contemporary serologic surveys confirm a high prevalence for neutralizing antibodies to type $3,{ }^{1,}{ }^{45}$ we have evidence that this high prevalence may be the result of relatively recent events. A survey of sera taken between 1950 and 1953 from the same population showed that only 20 per cent of the children and adults (to age 35 ) had neutralizing antibodies to type $3 .{ }^{46}$ It was shortly after this (1954) that outbreaks of pharyngoconjunctival fever due to type 3 were observed not only in various parts of the United States and Canada but also in many European countries and Australia, Japan, and Formosa as well. ${ }^{43,46-53}$ Outbreaks of pharyngoconjunctival fever have not been reported in the United States since 1960; this is not unexpected since the high prevalence of neutralizing antibodies reported for all the areas surveyed would preclude epidemic occurrences of type 3. However, continuing studies of adenovirus prevalence among the clinic patients attending the Washington, D. C., Children's Hospital show that type 3 is the most frequent adenovirus cause of febrile respiratory illnesses. $^{1}$ Prevalences of antibodies to adenovirus types 7, 12, and 18, insofar as they are known, appear to be quite low in those childhood populations which reveal high rates of adenovirus 3 neutralizing antibodies. ${ }^{1,37,40,43}$ Should the adenoviruses which are oncogenic in hamsters, rats, and mice also manifest oncogenic activity in man, then type 3 would have to be regarded as the prime suspect, if only because, among the known oncogenic adenoviruses, type 3 in recent years is the only serotype which has had an opportunity to infect most humans at an early age. However, it should be stated that as yet no evidence has been presented which suggests that any of the adenoviruses are oncogenic in man.

* This work was partially supported by the National Cancer Institute Field Studies, contract PH-43-64-941 with Microbiological Associates, Inc. 
$\dagger$ National Institute of Allergy and Infectious Diseases, Laboratory of Infectious Diseases.

$\ddagger$ Microbiological Associates, Inc.

${ }^{1}$ Parrott, R. H., R. M. Chanock, H. W. Kim, and A. J. Vargosko, unpublished data.

2 Trentin, J. J., Y. Yabe, and G. Taylor, "The quest for human cancer viruses," Science, 137, 835 (1962).

${ }^{3}$ Huebner, R. J., W. P. Rowe, and W. T. Lane, "Oncogenic effects in hamsters of human adenovirus types 12 and 18," these Procendings, 48, 2051 (1962).

${ }^{4}$ Girardi, A. J., M. R. Hilleman, and R. E. Zwickey, "Tests in hamsters for oncogenic quality of ordinary viruses including adenovirus type 7," Proc. Soc. Exptl. Biol. Med., 115, 1141 (1964).

${ }^{5}$ Huebner, R. J., M. J. Casey, R. M. Chanock, and W. T. Lane, unpublished data.

${ }^{6}$ Larson, V. M., A. J. Girardi, M. R. Hilleman, and R. E. Zwickey, "Studies of oncogenicity of adenovirus type 7 viruses in hamsters," Proc. Soc. Exptl. Biol. Med., 118, 15 (1965).

${ }^{7 a}$ Huebner, R. J., W. P. Rowe, H. C. Turner, and W. T. Lane, "Specific adenovirus complement-fixing antigens in virus-free hamster and rat tumors," these Proceedings, 50, 379 (1963).

${ }^{7 b}$ Sabin, A. B., H. M. Shein, M. A. Koch, and J. R. Enders, "Specific complement-fixing tumor antigens in human cells morphologically transformed by SV40 virus," these Proceedings, 52, 1316 (1964).

${ }^{7 c}$ Sabin, A. B., and M. A. Koch, "Behavior of noninfectious SV40 viral genome in hamster tumor cells: Induction of synthesis of infectious virus," these Proceedings, 50, 407-417 (1963).

${ }^{8}$ Hoggan, M. D., W. P. Rowe, P. H. Black, and R. J. Huebner, "Production of "tumor-specific' antigens by oncogenic viruses during acute cytolytic infections," these Proceedings, 53, 12 (1965).

${ }^{9}$ Huebner, R. J., "Manifestations of virus-specific antigens in virus-induced tumor cells. Theoretical and practical considerations," Proc. Sixth Canadian Cancer Conference (1964), in press.

${ }^{10 a}$ Huebner, R. J., "Non-virion neoantigens in cells infected with and transformed by viruses," presented in May 1965 at the International Conference on Tumor Antigens in Sukhumi, USSR, sponsored by Union Internationale Contre le Cancer, Geneva, Switzerland.

${ }^{10 b}$ Habel, K., "Specific complement-fixing antigens in polyoma tumors and transformed cells," Virology, 25, 55 (1965).

${ }^{10 c}$ Green, M., personal communication.

${ }^{11}$ Pereira, M. S., H. G. Pereira, and S. K. R. Clarke, "Human adenovirus type 31. A new serotype with oncogenic properties," Lancet, I, 21 (1965).

12 Performed on contract PH-43-63-81 by I)r. Charles Calisher and Miss Sue H. Hollinger of Microbiological Associates, Inc.

${ }^{13}$ Rowe, W. P., J. W. Hartley, and R. J. Huebner, "Serotype composition of the adenovirus group," Proc. Soc. Exptl. Biol. Med., 97, 465 (1958).

${ }^{14}$ Uchida, S., T. Hoshika, H. Yamamoto, K. Koike, S. Koseki, and A. Furuno, "Relationships between types of adenovirus indicated by heterologous neutralization," Japan. J. Exptl. Med., 29, 121 (1959).

${ }^{15}$ Rafajko, R. R., "Production and standardization of adenovirus types 1 to 18 reference antisera," Am. J. Hyg., 79, 310 (1964).

${ }^{16}$ Wigand, R., H. Bauer, F. Lang, and W. Adam, "Neutralization of the adenoviruses types 1 to 28: Specificity and antigenic relationships," Arch. Ges. Virusforsch., 15, 188 (1965).

${ }^{17}$ Hilleman, M. R., F. J. Flatley, M. L. Anderson, M. L. Luecking, and D. J. Levinson, "Antibody response in volunteers to adenovirus vaccine and correlation of antibody with immunity," J. Immunol., 80, 299 (1958).

${ }^{18}$ Ginsberg, H. S., "Biological and physical properties of the adenoviruses," Ann. N.Y.Acad. Sci., 67, 383 (1957).

19 Van der Veen, J., and A. Prins, "Studies of the significance of the recall phenomenon in the antibody response to adenovirus vaccine and infection," J. Immunol., 84, 562 (1960).

${ }^{20}$ Van der Veen, J., and G. Kok, "Isolation and typing of adenoviruses recovered from military recruits with acute respiratory disease in the Netherlands," Am. J. Hyg., 65, 119 (1957).

${ }^{21}$ Van der Veen, J., and J. H. Dijkman, "Association of type 21 adenovirus with acute respiratory illnesses in military recruits," Am. J. Hyg., 76, 149 (1962).

${ }^{22}$ Rosen, L., "A hemagglutination-inhibition technique for typing adenoviruses," Am. J. Hyg., $71,120(1960)$. 
${ }^{23}$ Rosen, L., S. Baron, and J. A. Bell, "Four newly recognized adenoviruses," Proc. Soc. Exptl. Biol. Med., 107, 434 (1961).

${ }^{24}$ Huebner, R. J., "The adenoviruses: general properties, clinical picture, and laboratory diagnosis," Proc. Intern. Congr. Tropical Med. Malaria, 5, 499 (1958).

${ }^{25}$ Ginsberg, H. S., "Characteristics of the new respiratory viruses (adenoviruses). I. Qualitative and quantitative aspects of the neutralization reaction," J. Immunol., 77, 271 (1956).

${ }^{26}$ Binn, L. N., M. R. Hilleman, J. E. Rodriguez, and R. R. Glabere, "Antigenic relationships among adenoviruses with appraisal of reliability of complement fixation test for typing isolates," J. Immunol., 80, 501 (1958).

${ }^{27}$ Ginsberg, H. S., "Newer aspects of adenovirus infections," Am. J. Public Health, 49, 1480) (1959).

${ }^{28}$ Denny, F. W., Jr., and H. S. Ginsberg, "Certain biological characteristics of adenovirus types 5, 6, 7 and 14,' J.Immunol., 86, 567 (1960).

${ }^{29} \mathrm{Piña}, \mathrm{M}$. and M. Green, manuscript in preparation.

${ }^{30}$ Schmidt, N. J., C. J. King, and E. H. Lennette, "Hemagglutination and hemagglutinationinhibition with adenovirus type 12," Proc. Soc. Exptl Biol. Med., 118, 208 (1965).

${ }^{31}$ Pope, J. H., and W. P. Rowe, "Detection of specific antigen in SV 40 transformed cells by immunofluorescence," J. Exptl. Med., 120, 121 (1964).

${ }^{32}$ Rapp, F., J. S. Butel, and J. L. Melnick, "Virus-induced intranuclear antigen in cells transformed by Papovavirus SV 40," Proc. Soc. Exptl. Biol. Med., 116, 1131 (1964).

${ }^{33}$ Bell, J. A., W. P. Rowe, J. I. Engler, R. H. Parrott, and R. J. Huebner, "Pharyngoconjunctival fever. Epidemiological studies of a recently recognized disease entity," J. Am. Med. Assoc., 157, 1083 (1955)

${ }^{34}$ Bell, J. A., R. J. Huebner, L. Rosen, W. P. Rowe, R. G. Cole, F. M. Mastrota, T. M. Floyd, R. M. Chanock, and R. A. Shvedoff, "Illness and microbial experiences of nursery children at Junior Village," Am. J. Hyg., 74, 267 (1961).

${ }^{35}$ Bell, J. A., W. P. Rowe, and L. Rosen, "Acute respiratory diseases of viral etiology. II. Adenoviruses," Am. J. Public Health, 52, 902 (1962).

${ }^{36}$ Huebner, R. J., W. P. Rowe, and R. M. Chanock, "Newly recognized respiratory tract viruses," Ann. Rev. Microbiol., 12, 49 (1958).

${ }^{37}$ Van der Veen, J., "Infections with adenovirus in Europe," Ann. Soc. Belge Med Trop., 38, 891 (1958).

${ }^{38}$ Grayston, J. T., C. G. Loosli, P. B. Johnson, M. E. Smith, and R. L. Woolridge, "Neutralizing and complement-fixing antibody response to adenovirus infection," J. Infect. Diseases, 99, 199 (1956).

${ }^{39}$ Jordan, W. S., "Occurrence of adenovirus infections in civilian populations," A.M.A. Arch. Internal Med., 101, 54 (1958).

${ }^{40}$ Jackson, G. G., "Viruses of the upper respiratory tract," Ann. Rev. Med., 77, 1 (1956).

${ }^{41}$ Munro-Ashman, I), P. S. Gardner, C. E. D. Taylor, and J. C. McDonald, "Acute pharyngitis associated with adenovirus type-3 infection," Lancet, 121 (1958).

${ }^{42}$ Fukumi, H., F. Nishikawa, H. Mizutani, Y. Yamaguchi, and J. Nanba, "An epidemic of adenovirus type 3 infections among school children in an elementary school in Tokyo," Japan. J. Med. Sci. Biol., 11, 129 (1958).

${ }^{43}$ Dreizin, R. S., E. E. Zolotarskaia, and A. A. Davydova, "Immunologic structure by age groups of the population in Moscow to adenoviruses," Vopr. virusologii 7, 85 (1962).

${ }^{44}$ Nolan, K., R. L. Doherty, D. Hart, and T. R. Biggs, "Adenovirus type 3 infection in Brisbane," Med. J. Australia, 1, 236 (1962).

${ }^{45}$ Lewis, A. M., Jr., R. J. Huebner, and R. R. Rafajko, unpublished data.

${ }^{46}$ Huebner, R. J., W. P. Rowe, T. G. Ward, R. H. Parrott, and J. A. Bell, "Adenoidal-pharyngeal-conjunctival agents. A newly recognized group of common viruses of the respiratory system," New Engl. J. Med., 251, 1077 (1954).

${ }^{47}$ Parrott, R. H., W. P. Rowe, R. J. Huebner, H. W. Bernton, and N. M. McCullough, "Outbreak of febrile pharyngitis and conjunctivitis associated with type 3 adenoidal-pharyngealconjunctival virus infection," New Engl. J. Med., 251, 1087 (1954).

${ }^{48}$ Sobel, G., B. Aronson, S. Aronson, and D. Walker, "Pharyngoconjunctival fever," A.M.A. J. Diseases Children, 92, 596 (1956). 
${ }^{49}$ Barr, J., L. Kjellén, and A. Svedmyr, "Hospital outbreak of adenovirus type 3 infections, a clinical and virologic study of 38 patients partly involved in a nosocomial outbreak," Acta Paediat., 47, 365 (1958).

${ }^{50}$ Kendall, E. J. C., R. W. Riddle, H. A. Tuck, K. S. Rodan, B. E. Andrews, and J. C. McDonald, "Pharyngo-conjunctival fever. School outbreaks in England during the summer of 1955 associated with adenovirus types 3, 7 and 14," Brit. Med. J., 2, 131 (1957).

${ }^{51}$ Kjellén, L., B. Zetterberg, and A. Svedmyr, "An epidemic among Swedish children caused by adenovirus type 3," Acta Paediat., 46, 561 (1957).

${ }^{52}$ Fukumi, H., F. Nishikawa, K. Nakamura, T. Watanabe, T. Kitayama, and C. Fujita, "Studies on the adenovirus as an etiological agent of pharyngoconjunctival fever," Japan. J. Med. Sci. Biol., 10, 79 (1957).

${ }^{53}$ Tai, F., and J. T. Grayston, "Adenovirus neutralizing antibodies in persons on Taiwan," Proc. Soc. Exptl. Biol. Med., 109, 881 (1962).

\title{
THEORY OF THE FLOW OF ACTION CURRENTS IN ISOLATED MYELINATED NERVE FIBERS, IV*
}

\section{By R. Lorente de Nó and V. Honrubia $†$}

\author{
THE ROCKEFELLER INSTITUTE
}

Communicated May 28, 1965

We continue the presentation of the theory of the isolated fiber. ${ }^{1}$ To facilitate cross references the number of the figures in preceding communications will be preceded by the corresponding reference. For example, $1 c$, Figure 3 is Figure 3 in reference $1 c$.

Technique of Interpretation of Electrical Recordings.-The diagrams in Figures 1-3 illustrate the physical meaning of equations (1), (2), and (4) of reference $1 b$. They present instantaneous distributions of action currents (external and membrane) and of external action potential, $-V_{e}$, in the Ringer pools and in the recording gaps at selected instants during the propagation of an impulse along the isolated segment of fiber.

The diagrams consider situations that arise when the amplifier is in position $I V$ ( $1 b$, Fig. 1) and node $N_{1}$ is located in the central pool $(I-V)$, or at the center of the first gap $(V I)$. According to the uncertainty principle ${ }^{1 d}$ the distributions of potential given in the diagrams in general do not apply to the situations which arise when the amplifier is placed in positions $I$ or $I I$, but they do apply to those particular instances in which, owing to the presence of suitable external shunts, the impulse propagates itself in approximately the same ways when the amplifier is in positions $I, I I$, or $I V$. As was explained in ref. 1c (Fig. 3), after active zone $a$ has reached a certain position, the impulse executes successive jumps, whereby additional active zones $\left(b, c\right.$ or $\left.b_{1}, b_{2}, c\right)$ are created in rapid succession and, since the active zones coexist for significant periods of time, the external longitudinal current flows in two or more directions in each recording gap.

The diagrams indicating the flow of action currents are self-explanatory; they are intended to indicate only the direction of flow; the magnitude of the longitudinal flow of current at any given point of the recording gaps is measured by the slope that the distribution of external potential has at that point. On the other hand, since the distributions of potential are only approximate, their didactic value can be increased by assuming that, when their ordinate values are measured from suitable base lines (labeled $i_{m}=0$ in Fig. 1, Ia), the $-V_{e}$ curves also give the distributions of the density of the flow of membrane current in the still inactive segments of fiber, in which an outward flow is taking place. The assumption is not far from the truth, because in those segments the distributions of potential must be nearly exponential.

The diagrams of the distributions of external potential $-V_{e}$ can easily be read if the following circumstances are taken into account. Since in the Ringer pools the flows of external action cur- 